\title{
Anti-ulcerogenic Action Mechanism of Maytenus ilicifolia Detected by mRNA RT-PCR and Free Radical Scavenging Activity Evaluated by ESR
}

\author{
Dalva Pazzini ${ }^{1}$, Elder Bruno Fontes ${ }^{1}$, Ana Paula D. Hory ${ }^{1}$, Adevailton B. Santos ${ }^{2}$, Oswaldo Baffa ${ }^{3}$, \\ Rosângela Bezerra ${ }^{4}$, Silvana Pasetto ${ }^{5}$, Eduardo José Crevelin ${ }^{6}$, Luiz Alberto Beraldo Moraes ${ }^{6}$, \\ Angela Kinoshita $^{1, *}$, Ana Cláudia B. Paula-Zurron ${ }^{7}$ \\ ${ }^{1}$ Pró-Reitoria de Pesquisa e Pós-Graduação, Universidade do Sagrado Coração - USC, Bauru, SP, Brazil \\ ${ }^{2}$ Universidade Federal de Uberlândia, Uberlândia, MG, Brazil \\ ${ }^{3}$ Departamento de Física, FFCLRP, Universidade de São Paulo- USP, Ribeirão Preto, SP, Brazil \\ ${ }^{4}$ Departamento de Clínica Médica, Universidade de Campinas- UNICAMP, Campinas, SP, Brazil \\ ${ }^{5}$ Centro Universitário do Norte, UniNorte Manaus, AM, Brazil \\ ${ }^{6}$ Departamento de Química, FFCLRP, Universidade de São Paulo- USP, Ribeirão Preto, SP, Brazil \\ ${ }^{7}$ Kroton Educacional, Valinhos, SP, Brazil
}

Email address:

angelamitie@gmail.com (A. Kinoshita), angela.kinoshita@usc.br (A. Kinoshita)

*Corresponding author

\section{To cite this article:}

Dalva Pazzini, Elder Bruno Fontes, Ana Paula D Hory, Adevailton B Santos, Oswaldo Baffa, Rosângela Bezerra, Silvana Pasetto, Eduardo José Crevelin, Luiz Alberto Beraldo Moraes, Angela Kinoshita, Ana Cláudia B. Paula-Zurron. Anti-ulcerogenic Action Mechanism of Maytenus ilicifolia Detected by mRNA RT-PCR and Free Radical Scavenging Activity Evaluated by ESR. American Journal of Health Research. Vol. 5, No. 3, 2017, pp. 57-64. doi: 10.11648/j.ajhr.20170503.12

Received: February 24, 2017; Accepted: March 24, 2017; Published: March 30, 2017

\begin{abstract}
Maytenus ilicifolia, known as "espinheira-santa", is used in the popular medicine for peptic ulcer treatment. This work evaluates the preventive and curative actions of M. ilicifolia in animals, the healing activity by EGF expression detected by RT-PCR as well as the anti-oxidative activity by Electron Spin Resonance spectroscopy (ESR). Oral administration of $M$. ilicifolia (300 and $500 \mathrm{mg} / \mathrm{kg}$, p.o.) one hour before the ulcerogenic agent application prevented the ulcer formation $42 \pm 0.98 \%$ and $72 \pm 1.2 \%$ ( $<<0.05$ and $p<0.001$, respectively), in comparison with the negative control tween 80 , preserving the cytoprotection characteristics of the gastric mucosa and assuring the integrity of gastric glands and gastric fossets. The animals treated with tween, had the epithelium and the mucosa layer damaged and accentuated vascularization. The healing activity of $M$. ilicifolia $(500 \mathrm{mg} / \mathrm{kg}$, p.o.) was $71 \pm 1.4 \%(\mathrm{p}<0.001)$ in chronic ulcer experiments induced by acetic acid. EGF expression detected by RT-PCR confirmed the healing activity. Histological analysis showed the recovery of the mucosal layer and the epithelium surface harmed by the acetic acid. Studies in vitro by Electron Spin Resonance spectroscopy assessed the anti-oxidative action of $M$ ilicifolia. Experiments with DPPH (2.2Diphenyl -1-picrylhydrazyl) demonstrated that the polar fraction of $M$. ilicifolia presents an $\mathrm{IC}_{50}$ of $0.68 \pm 0.09 \mathrm{mg} / \mathrm{ml}$. The value of $9 \pm 2 \mathrm{mg} / \mathrm{ml}$ was found for $\mathrm{IC}_{50}$ in experiments with the radical $\mathrm{OH}$, produced by the Fenton Reaction and detected through spin adduct DMPO-OH. Mass spectrometry analysis of crude extracts and fractions from M. ilicifolia was carried out and compounds of pentacyclic triterpenes class were identified.
\end{abstract}

Keywords: Maytenus ilicifolia, Anti-oxidative Activity, Antiulcerogenic Activity, Epidermal Growth Factor, Gastric Ulcer, Electron Spin Resonance 


\section{Introduction}

Maytenus ilicifolia (Celastraceae) popularly known in Brazil as "espinheira-santa" (holy spines) is a native plant from southern Brazil, Paraguay, Uruguay and northern Argentina [1]. It is used in folk medicine for the treatment of dyspepsia as well as gastric ulcers and potentially on cancer treatment [2]-[4]

Cipriani et al. demonstrated, after several purification steps, that the tea (infusion) of $M$. ilicifolia leaves releases a polysaccharide (arabinogalactan). The pre-treatment with arabinogalactan practically abolished the ethanol-induced gastric damage, suggesting a potential ability to bind to the surface mucosa and function as a protective coating, antisecretory activity, and mucosal protection by increased mucus synthesis, and radical scavenging [5].

Triterpenes, isolated from Maytenus spp. and identified in hexane extract, have compounds potentially antiulcerogenic due to their ability of stimulating the synthesis of mucus or the maintenance of the prostaglandin contents of gastric mucosa at high levels. Antiulcerogenic effect was also observed in the ethyl acetate extract and the presence of condensed tannins and flavonoids was observed. Because of anti-inflammatory activity, without gastric irritation and of mucosa protection, hexane and ethyl acetate extracts of Maytenus ilicifolia may represent an important clinical alternative both in inflammation and in antiulcerogenic therapeutics [6].

Paula et al. described that the mechanism of action of the essential oil obtained from the bark of Croton cajucara in chronic gastric ulcer occurred by enhancing EGF expression detected by RT-PCR in rats. Considering that EGF and TGF $\alpha$ are effective at protecting the gastric mucosa from acetic cidinduced gastric lesions, it is reasonable to assume that these factors limit mucosal damage caused by ulcerogenic agents, aiding early mucosal restoration [7].

The crude ethanolic extract of $M$. ilicifolia has a powerful antioxidant potential [3]. Polyphenols and flavonoids are plant constituents with possible action in the free radical scavenging action, and they are present in M. ilicifolia [8]. Free radicals and reactive oxygen species are involved in a variety of pathological events like diabetes, cancer and aging. Oxygen-derived free radicals have recently been postulated to play an important role in the pathogenesis of acute gastric mucosal injury induced by ischemia-reperfusion, stress, ethanol and anti-inflammatory drugs in rats. Furthermore, it has been suggested that free radicals generated by neutrophils may be important factors in delaying the healing of acetic acid-induced chronic gastric ulcers in these animals [9]. This work evaluates the preventive and curative actions of $M$. ilicifolia in animals, the healing activity by EGF expression detected by RT-PCR as well as the anti-oxidative activity by Electron Spin Resonance spectroscopy (ESR). In addition, mass spectrometry (MS) analysis of M. ilicifolia was carried out to identify its main class of compounds present in the crude ethyl acetate extract.

\section{Material and Methods}

\subsection{Chemicals and Biochemical}

Tween, acetic acid, ethanol solution (Sigma Chemical São Paulo, Brazil), lanzoprazole, ranitidine (Glaxo Smith Kline, Rio de Janeiro, Brazil), xylazine hydrochloride, ketamine (Pfizer, São Paulo, Brazil), Maytenus ilicifolia (Espinheira Santa Herbarium Laboratories ${ }^{\circledR}-C u r i t i b a$, Paraná, Brazil). DPPH (2,2-diphenyl-1-picryl-hydrazyl) and DMPO (5,5dimethyl-1-pyrroline N-oxide) were purchased from SigmaAldrich Co. (St. Louis, MO, USA) and have purity of $95 \%$ and $97 \%$, respectively. All other reagents used for ESR experiments and Mass spectrometry were of analytical grade. Guanidium iso thiocyanat|phenol chloroform kit, moloney murine leukemia virus reverse transcriptase (MMLV-RT) and oligo-(dt)- primers, RNase Block Ribonuclease Inhibitor were obtained from Stratagene, Heidelberg, Germany). Stand buffer, Taq polymerase (Pharmacia, Germany), $\mathrm{MgCl} 2, \mathrm{KCl}$, $\mathrm{HCl}$ (Takara, Shiga, Japan) also were used in this experiment EGF antisense primer was made by GIBCO BRL| Life Technologies-Eggenstein, Germany. Rat $\beta$ actin was obtained by Clon Tech, Palo Alto, CA.

\subsection{Plant Material}

Maytenus ilicifolia (Espinheira-Santa $\left.{ }^{\circledR}\right)$ was acquired from Herbarium Laboratories (Curitiba, Paraná, Brasil), and one capsule of $M$. ilicifolia contain $13.3 \mathrm{mg}(3.5 \%)$ of tannins.

For in vivo experiments, M. ilicifolia (300 and $500 \mathrm{mg} / \mathrm{kg}$ ) was diluted in tween (Tween $80 \circledR$ ), resulting in solutions with 30 and $50 \mathrm{mg} / \mathrm{ml}$, and administered by oral route in rats. Following, M. ilicifolia was diluted in water, heated, filtered, lyophilized and used for radical scavenging experiments by Electron Spin Resonance.

\subsection{Animals}

All experiments were performed on male Wistar rats (200$250 \mathrm{~g}$ ) from the Central Animal House of Universidade do Sagrado Coração (USC). The animals were fed a certified Nuvilab CR-a (Nuvital) diet and had free access to tap water. Mice were kept in the animal house under a standard $12 \mathrm{~h}$ light $/ 12 \mathrm{~h}$ dark cycle, $50 \%$ humidity and temperature of $24 \pm 1^{\circ} \mathrm{C}$. Experimental protocols were approved by the Ethics Committee of USC and were conducted according to recommendations of the Canadian Council on Animal Care All experiments were performed in the morning, according to guidelines for laboratory animal care and ethical guidelines for the investigation of experimental inflammation in conscious animals [10] [11].

\subsection{Ethanol Ulceration}

Wistar rats (200-250 g) were subjected to an ethanolinduced ulcer assay [12]. These rats were fasted for $24 \mathrm{~h}$ (free access to water) before the experiment. The animals then 
randomly received oral Tween $80 \circledR(10 \mathrm{ml} / \mathrm{kg}, \mathrm{N}=7)$, lanzoprazole Losec $\AA(30 \mathrm{mg} / \mathrm{kg}, \mathrm{N}=7)$ or Maytenus ilicifolia (300 and $500 \mathrm{mg} / \mathrm{kg}, \mathrm{N}=7$ ). One hour after treatment with the Tween, lanzoprazole and $M$. ilicifolia, $1 \mathrm{ml}$ of absolute ethanol was orally administered to the rats. Thirty minutes later, the animals were euthanized and their stomachs were removed to determine ulcer index [12].

\subsection{Chronic Ulcer Induced by Acetic Acid}

Wistar rats (200-250 g) were randomly allocated into one of 3 treatment groups, in which ulceration was induced by acetic acid according Takagi et al. [13]. Rats were then treated with $M$. ilicifolia $(500 \mathrm{mg} / \mathrm{kg})$, ranitidine $(100 \mathrm{mg} / \mathrm{kg})$ or Tween 80 , as a vehicle $(10 \mathrm{ml} / \mathrm{kg})$. Rats were anesthetized with xylazine hydrochloride $(50 \mathrm{mg} / \mathrm{kg})$ and ketamine $(180$ $\mathrm{mg} / \mathrm{kg}$ ) for the application of $50 \mathrm{ml}$ of $30 \mathrm{ml} / \mathrm{L}$ acetic acid solution into the subserosal stomach layer of each animal. Two days after surgery, the respective treatment drugs were orally administered once daily for 14 consecutive days. The animals were euthanized on the day after stopping drug administration. The ulcer area $\left(\mathrm{mm}^{2}\right)$ and curative ratio $(\%)$ were measured [12].

\subsection{Microscopic Analysis}

For morphological ulcer analysis, rat stomachs were fixed in Bouin for $24 \mathrm{~h}$, were dehydrated through ascending concentrations of ethyl alcohol, cleared with xylene, embedded in Histosec (Merck -11609), and prepared for microtomy. The $8 \mu \mathrm{m}$-sections were then stained with Hematoxilin and Eosin. Photomicrographs were obtained with microscope Nikon H550L.

\subsection{Molecular Assay}

Reverse-transcriptase polymerase chain reaction for detection of EGF $m R N A$

Molecular analyses were carried out only in animals treated with Maytenus ilicifolia (treated group) and Tween 80 (negative control group) in the chronic ulcer induced by acetic acid experiment. The total RNA was isolated from mucosal gastric samples and was stored at $-80^{\circ} \mathrm{C}$ [14]. Briefly, total RNA was extracted from mucosal samples using a single-step guanidium isothiocyanate/phenol chloroform extraction kit from Stratagene (Heidelberg, Germany) based on a method described by Chomczynski \& Sacchi [15]. After precipitation, RNA was resuspended in RNAse-free TE buffer and its concentration was estimated by absorbance at a wavelength of $260 \mathrm{~nm}$. Furthermore, the quality of each RNA sample was determined by running agarose-formaldehyde electrophoresis. The RNA samples were stored at $-80^{\circ} \mathrm{C}$ until required for analysis.

Single-stranded cDNA was generated from $5 \mu \mathrm{g}$ of total cellular RNA using Moloney murine leukemia virus reverse transcriptase (MMLV-RT) and oligo-(dT)-primers (Stratagene, Heidelberg, Germany). Briefly, $5 \mu \mathrm{g}$ of total RNA was uncoiled by heating $\left(65^{\circ} \mathrm{C}\right.$ for $\left.5 \mathrm{~min}\right)$ and was then reversely transcribed (at $37^{\circ} \mathrm{C}$ for 1 hour) into complementary DNA (cDNA) in a $50 \mu \mathrm{l}$ reaction mixture containing $50 \mathrm{U}$ MMLV-RT, $0.3 \mu \mathrm{g}$ oligo-(dT)-primer, $40 \mathrm{U}$ RNase Block Ribonuclease Inhibitor $(40 \mathrm{U} / \mu \mathrm{l}), 2 \mu \mathrm{l}$ of a 100 $\mathrm{mM} / 1$ mixture of deoxyadenosine triphosphate (dATP), deoxythymidine triphosphate (dTTP), deoxyguanosine triphosphate (dGTP) and deoxycytidine triphosphate (dCTP), $5 \mu \mathrm{l}$ of $10 \mathrm{X}$ first-strand buffer (all reagents were provided by Stratagene, Heidelberg, Germany). The resultant cDNA ( $2 \mu \mathrm{l})$ was amplified in a $50 \mu \mathrm{l}$ reaction volume containing $2 \mathrm{U}$ Taq polymerase, dNTP (200 $\mu \mathrm{M}$ each) (Pharmacia, Germany), $1.5 \mathrm{mM} \mathrm{MgCl} 2,5 \mu \mathrm{l} 10 \mathrm{X}$ polymerase chain reaction (PCR) buffer $(100 \mathrm{mM} \mathrm{KCl}, 20 \mathrm{mM}$ Tris- $\mathrm{HCl}, \mathrm{pH}=8.3)$ and specific primers used at a final concentration of $1 \mathrm{mM}$ (all reagents were from Takara, Shiga, Japan). The mixture was overlaid with $25 \mu \mathrm{l}$ of mineral oil to prevent evaporation. The PCR mixture was amplified in a DNA thermal cycler (Perkin-Elmer-Cetus, Norwalk, CT). Incubation and thermal cycling conditions were as follows: denaturation at $94^{\circ} \mathrm{C}$ for $1 \mathrm{~min}$, annealing at $60^{\circ} \mathrm{C}$ for $45 \mathrm{sec}$ and extension at $72^{\circ} \mathrm{C}$ for 2 min. PCR amplification proceeded for 33 cycles using AmpliWax $^{\circledR}$ PCR Gem 50 wax beads. The nucleotide sequence of sense primers was 5'GACAACTCCCCTAAGGCTTA-3' - nucleotides 28042823) and the EGF antisense primer (5'CATGCACAGGCCACCATTGAGGCAGTACCCATCGTA CGA-3' - nucleotides 3332-3370) synthesized by GIBCO BRL/Life Technologies (Eggenstein, Germany). Concomitantly, amplification of control rat $\beta$-actin (Clon Tech, Palo Alto, CA) was performed on the same samples to assess RNA integrity.

PCR products were detected by electrophoresis on a $1.5 \%$ agarose gel containing ethidium bromide. The location of predicted products was confirmed by using a 100-bp ladder (Takara, Shiga, Japan) as a standard size marker. The gel was then photographed under UV transillumination. The intensity of PCR products was measured using a video image analysis system (Kodak Digital Science).

\subsection{Free Radical Scavenging Tests}

Free radical scavenging activity of the $M$. ilicifolia was determined using stable DPPH (2,2-diphenyl-1-picrylhydrazyl) radical [16] [17] [18] [19] and hydroxyl radical, produced through Fenton reaction and monitored using DMPO (5,5-dimethyl-1-pyrroline $\mathrm{N}$-oxide) as a spin trap.

A volume of $100 \mu \mathrm{L}$ of the ethanolic solution of DPPH $1 \mathrm{mM}$ was mixed to $100 \mu \mathrm{L}$ of aqueous solution of lyophilized extract of $M$. ilicifolia in different concentrations, varying from 0 (reference) to $2.5 \mathrm{mg} / \mathrm{ml}$. This mixture was placed in a capillary tube and transferred to an ESR quartz tube. The reactions were carried three times and its spectrum was recorded in a Jeol FA-200 spectrometer, 3 minutes after reaction. The acquisition parameters were: central field $338 \mathrm{mT}$, modulation $0.1 \mathrm{mT}$, scan range $10 \mathrm{mT}$, scan time 1 minute, microwave power $2 \mathrm{~mW}$, below to the signal saturation in this system. The signal intensity of the central line was used to monitor the free radical concentration. The average of this intensity related to each extract concentration 
was plotted and an exponential function (1) was used to fit them and used to determine the $\mathrm{IC}_{50}$ :

$$
I=A e^{-b c}
$$

where I is the ESR signal intensity, c the concentration, A and $\mathrm{b}$ fitting parameters.

The Fenton reaction was carried using $50 \mu \mathrm{L}$ of $\mathrm{Fe}\left(\mathrm{SO}_{4}\right)$ $(10 \mathrm{mM}), \mathrm{H}_{2} \mathrm{O}_{2}(100 \mathrm{mM})$, DMPO $(200 \mathrm{mM})$ and phosphate buffer $(10 \mathrm{mM})$. To test hydroxyl radical scavenging activity, $50 \mu \mathrm{L}$ of aqueous solution of the lyophilized extract of $M$. ilicifolia in different concentrations ( 0 to $50 \mathrm{mg} / \mathrm{ml}$ ) was added. The ESR spectra were registered 3 minutes after reaction. The experiment was taken 3 times for each concentration and the acquisition parameters were the same of the DPPH experiment. The signal intensity of the first central line was used as parameter of the free radical concentration. The average of ESR signal intensity was plotted as a function of extract concentration and fitted by equation 1 to $\mathrm{IC}_{50}$ determination.

\subsection{Mass Spectrometry}

Mass spectrometry analysis was carried out with a LC-MS 1200L Triple Quadrupole (Varian) mass spectrometer equipped with a standard ESI (Electrospray Ionization) source operating in positive and negative modes. The ionization of compounds was better in positive mode. The tuning parameters for ESI-MS were: capillary voltage $3.2 \mathrm{kV}$, cone voltage $40 \mathrm{~V}$, source temperature $100^{\circ} \mathrm{C}$, desolvation temperature $200^{\circ} \mathrm{C}$. The samples were dissolved in $\mathrm{MeOH}$ (Methanol) and injected by direct insertion.

\subsection{Extraction of Compounds}

The lyophilized extract $(0.5 \mathrm{~g})$ of the leaf of $M$. ilicifolia was dissolved in $20 \mathrm{ml}$ of $\mathrm{H}_{2} \mathrm{O}$ and partitioned with an equal volume of Hex (Hexane), EtOAc (Ethyl Acetate and $\mathrm{BuOH}$ (Buthanol) (3 $\mathrm{x})$ (Figure 1). The organic layer was washed with saturated $\mathrm{NaCl}$ solution, dried with anhydrous $\mathrm{Na}_{2} \mathrm{SO}_{4}$ and concentrated in rotatory evaporator (Büchi B-480) to afford the crude extracts Hex (25 mg), EtOAc (230 mg) and BuOH (30 mg).

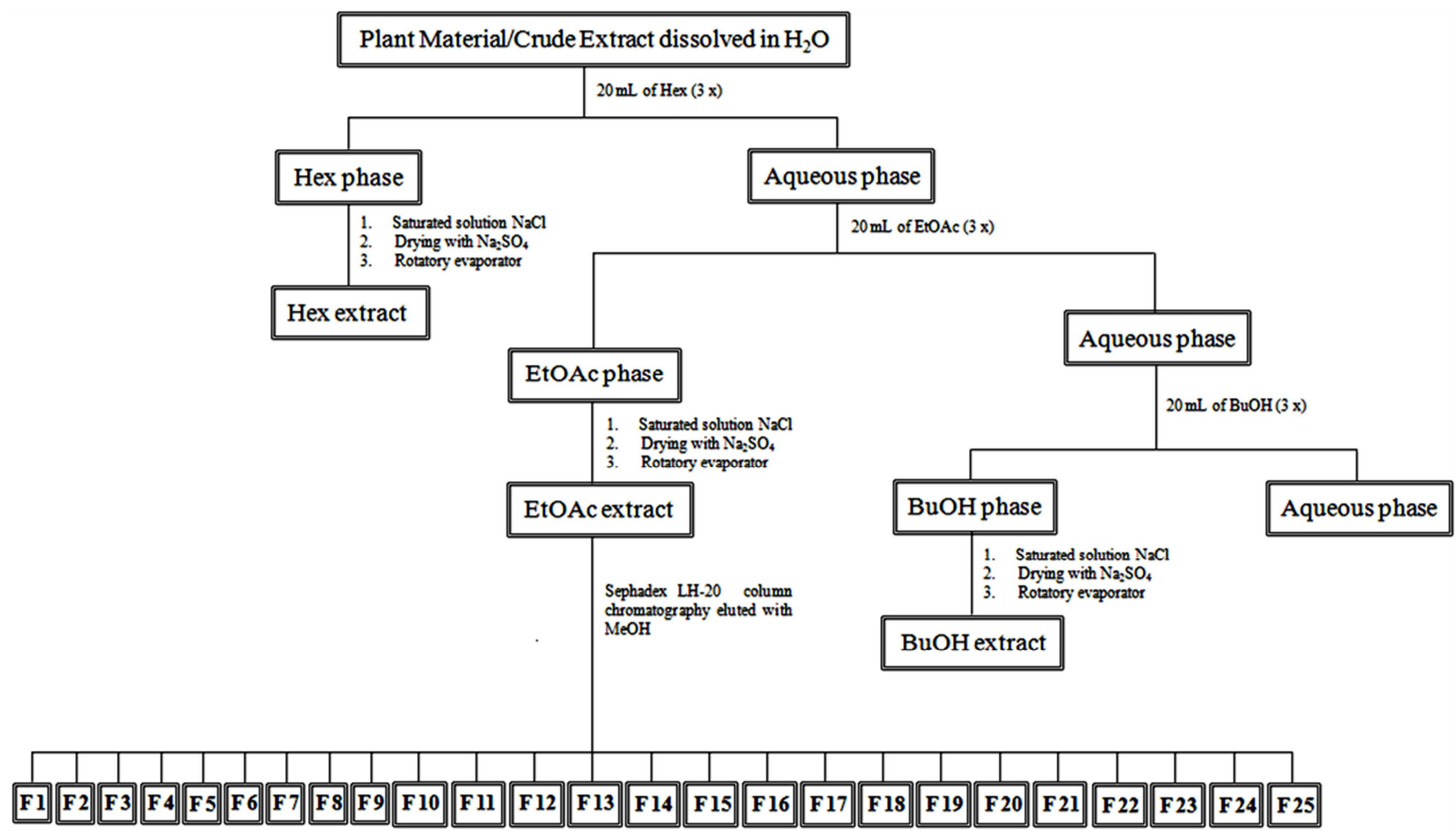

Figure 1. Methodology used to obtain the fractions of M. ilicifolia. Part of the crude extract EtOAc (215 mg) was fractionated on a Sephadex LH-20 column (1 $\mathrm{m} \times 3 \mathrm{~cm}$ i.d., Pharmacia) eluted with $\mathrm{MeOH}$. A total of 25 fractions of $5 \mathrm{ml}$ each were collected.

\subsection{Statistical Analysis}

Anti-ulcerogenic results were expressed as mean \pm S.E. One-way variance analysis was followed by Dunnett's, Scheffe's and Tukey's tests. These tests were run in the Statistical 5.1 software (Stat Soft, Inc). The level of significance was set at $p<0.05$. The experimental data points of ESR signal intensity were fitted using software Microcal Origin 8.5 (Northampton, USA) for $\mathrm{IC}_{50}$ calculations and were represented by mean \pm S.D.

\section{Results and Discussion}

\subsection{Ethanol Ulceration}

Oral treatment with ethanol causes focal hyperemia, edema, necrosis and submucosal hemorrhage, as well as circulatory disturbances [20]. The extent of ethanol-induced gastric mucosal damage in rats correlates with the number of degranulating mast cells since these cells are a source of several neuropeptides and inflammatory mediators, including histamine and leukotrienes [21]. 


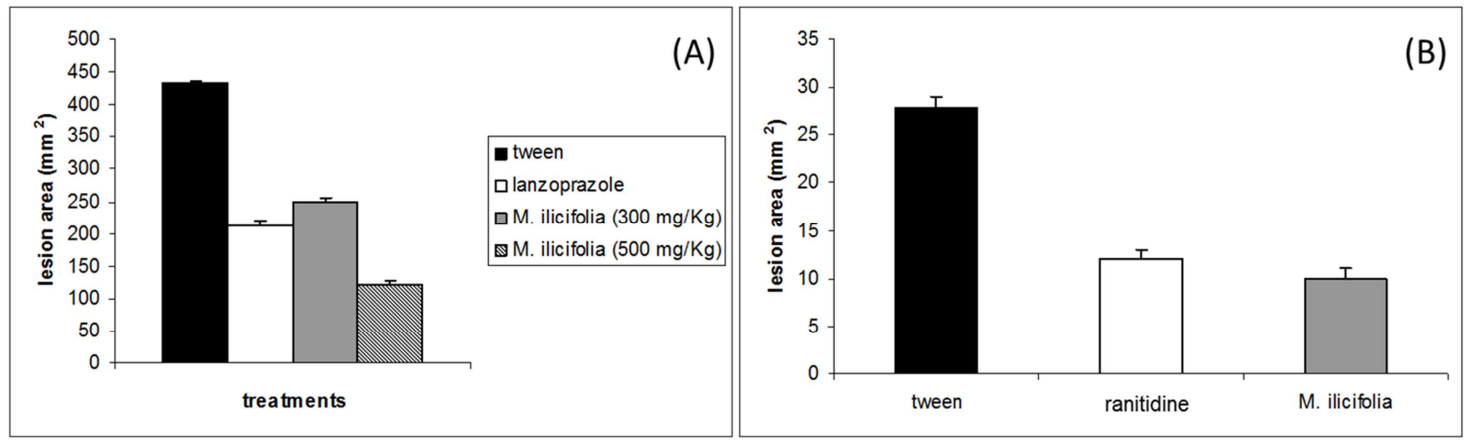

Figure 2. (A) Preventive effect of Maytenus ilicifolia (300 and $500 \mathrm{mg} / \mathrm{kg}$ ) and the positive control lanzoprazole in ethanol acute gastric ulcer model. Each value is the mean \pm S.E.M for 7 animals. ANOVA $F_{(3,24)}=3,20$ para ILU $\left(\mathrm{mm}^{2}\right)$. Teste de Tukey: $* p<0.05 e^{* *} p<0.001$. (B) Lesion area due to acetic acid administration in gastric mucosa of rats. The animals were treated by 14 days with tween (negative control), ranitidine (positive control) and Maytenus ilicifolia. Each value is the mean \pm S.E.M for 7 animals. ANOVA $F_{(2,18)}=2,84$ para ILU $\left(\mathrm{mm}^{2}\right)$. Teste de Dunnett's: ** $p<0.001$.

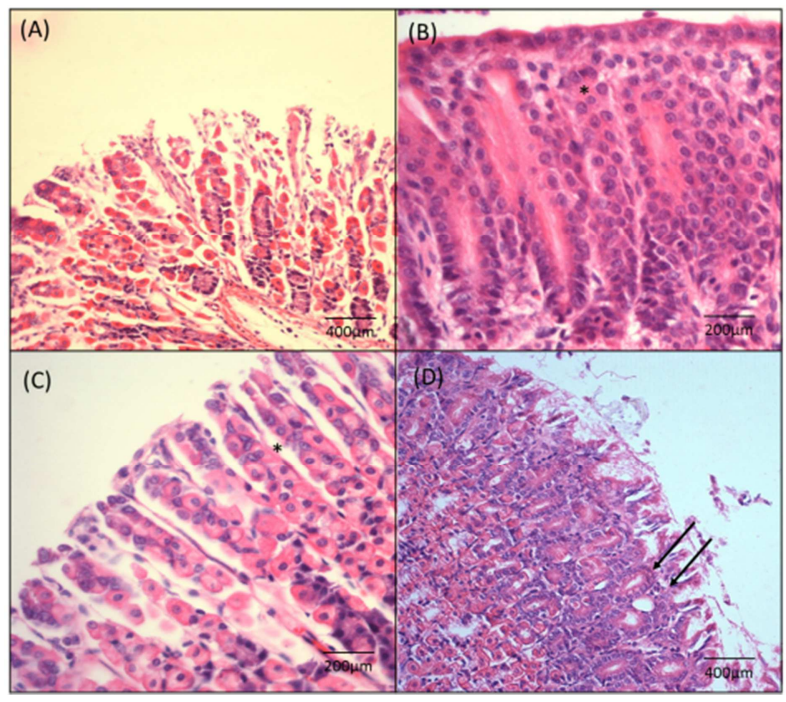

Figure 3. Photomicrographs of ulcer treatments induced by ethanol solution (A) negative control group (tween), glandular epithelium partially destroyed (open arrows). Pre-treatments with extract of Maytenus ilicifolia; $300 \mathrm{mg} / \mathrm{kg}$ (B) and $500 \mathrm{mg} / \mathrm{kg}(\mathrm{C})$ : to observe intact gastric mucosa, with glands and gastric pits (asterisks) very visible. (D) pre-treatment with anti-ulcerogenic drug lanzoprazole $30 \mathrm{mg} / \mathrm{kg}$, intact and continuous glandular epithelium (black arrows). Haematoxiline \& Eosine.

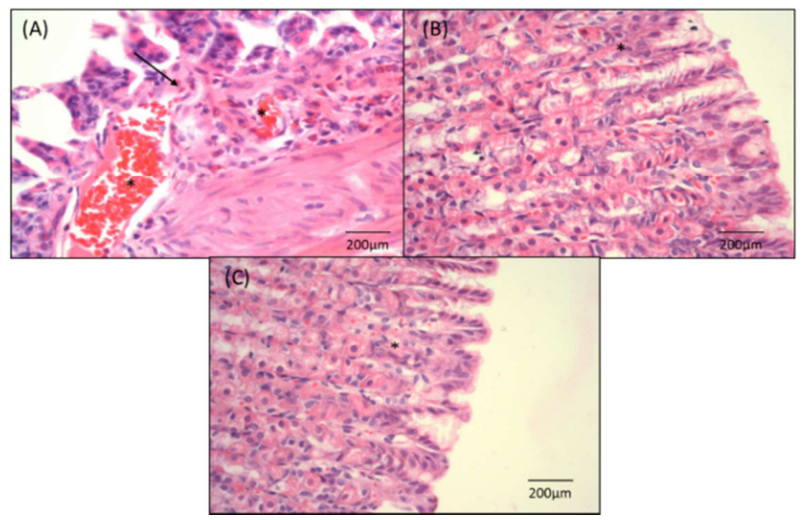

Figure 4. Photomicrographs of the treatments of chronic ulcer induced by acetic acid solution. Negative control group (tween) (A): atrophic epithelium glandular with intense hyperemia (asterisks). Treatment with Maytenus ilicifolia at the dose of $500 \mathrm{mg} / \mathrm{kg}$ (B); and treatment with ranitidine 100 $\mathrm{mg} / \mathrm{kg}(\mathrm{C})$ : to observe the glands and gastric pits (asterisks) continuous, without sign of atrophy of the tissue. Haematoxiline \& Eosine.
The effect of M. ilicifolia on gastric ulcers induced by ethanol is shown in Figure 2A. In this acute experiment, the lesion areas of rats undergoing Tween 80 treatment were $7.42 \pm 0.40 \mathrm{~mm}^{2}$ and animals undergoing Maytenus ilicifolia (300 and $500 \mathrm{mg} / \mathrm{kg}$ ) treatment showed smaller lesion areas: $3.12 \pm 0.80 \mathrm{~mm}^{2}$ and $5.34 \mathrm{~mm}^{2} \quad(\mathrm{p}<0.05$ and $\mathrm{p}<0.001$, respectively), when compared with the negative control tween 80. The oral administration of ethanol solution on the negative control group (pre-treated with tween) caused necrotizing gastric mucosa lesions, observed by the tissue disorganization, lack of continuous glandular epithelium and own lamina formed by connective tissue (Figure $3 \mathrm{~A}$ and $\mathrm{B}$ ).

Maytenus ilicifolia (300 and $500 \mathrm{mg} / \mathrm{kg}$, p.o.) and the positive control lanzoprazole $(30 \mathrm{mg} / \mathrm{kg}$, p.o.) significantly inhibited the lesions formation in the gastric mucosa. The treated animals with $M$. ilicifolia showed intact gastric glands and mucosa, with the continuous coating epithelium (Figure $3 \mathrm{C}, \mathrm{D}$ and F). Intact glandular epithelium was also observed in the lanzoprazole group (Figure $3 \mathrm{G}$ and $\mathrm{H}$ ). This protection could reflect the inhibition of gastric secretion or an increase in the release of protective substances by the mucosa as reported by Jorge et al. [6] that related an anti-inflammatory and antinociceptive activities and protection against gastric lesions, including cytoprotection and healing.

\subsection{Chronic Ulcer Induced by Acetic Acid}

The healing effect of M. ilicifolia was demonstrated because the healing of chronic gastric ulcer induced by acetic acid in rats was accelerated. Postoperative treatment with ranitidine and $M$ ilicifolia $(500 \mathrm{mg} / \mathrm{kg})$ for 14 consecutive days accelerated the ulcer healing. On day 14 after surgery, the percentage of rats with cicatrized ulcers in both experimental groups was significantly higher than in the negative control group (Figure 2B). In addition, M. ilicifolia and ranitidine significantly healed the chronic gastric ulcer reducing its area in $71.3 \pm 1.4 \%$ and $54.5 \pm 1.6 \%$ (respectively) when compared with the negative control tween $80(\mathrm{p}<0.001)$.

The ulcer induction by acetic acid solution was verified in the negative control group (treated with tween) for 14 consecutive days. The ulcerogenic agent caused 
disorganization on part of the mucosa, with atrophy of the glandular epithelium and intense hyperemia (Figure $4 \mathrm{~A}$ and B).

Maytenus ilicifolia $(500 \mathrm{mg} / \mathrm{kg})$ and the anti-ulcerogenic drug ranitidine $(100 \mathrm{mg} / \mathrm{kg})$ were efficient on the treatment of gastric mucosa lesions. The treatment with $500 \mathrm{mg} / \mathrm{kg}$ of Maytenus ilicifolia for 14 consecutive days caused gastric mucosa regeneration, intact and continuous superficial epithelium, with well defined glands and gastric pits. The tissue also presented hyperemia (figure $4 \mathrm{C}$ and D). The same was observed in the animals treated with ranitidine $(100 \mathrm{mg} / \mathrm{kg}$ ) (figure $4 \mathrm{E}$ and $\mathrm{F}$ ): continuous superficial epithelium, own lamina and complete gastric gland. But the hyperemia was more intense than in the treated group.

\subsection{Molecular Assay}

Several authors associate the antiulcerogenic process with healing of chronic ulcer and participation of protein of epidermal growth factor (EGF). EGF is a 53-amino acid peptide originating mainly from the salivary glands. EGF mRNA has not been detected in the intact gastric mucosa of rodents and humans [22].

Growth factors and their receptors play important roles in cell proliferation and migration, repair of tissue injury and ulcer healing [23]. Paula et al. [7] related that the essential oil obtained of Croton cajucara healed the chronic gastric ulcer increasing EGF mRNA expression detected by RT-PCR and also increased somatostatin plasma levels and consequent gastrin plasma levels.

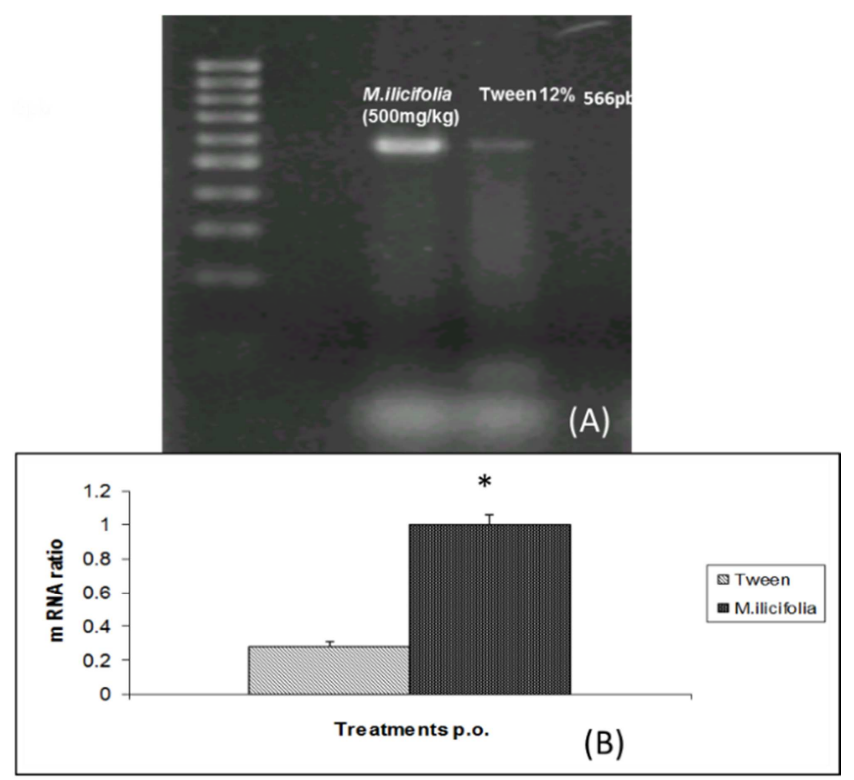

Figure 5. (A) Expression of $m R N A$ of EGF after the treatment of Maytenus ilicifolia $(500 \mathrm{mg} / \mathrm{kg})$ by 14 days on acetic-acid chronic ulcer and analyzed by RT-PCR in rats. (B) Densiometric data Expression of mRNA of EGF. Results are presented as mean $\pm S D$ of 9 rats in each group. ANOVA, Dunnett's test: *p<0.01.

In experiments with chronic acetic acid-induced ulceration, mRNA was identified in the mucosa of rats treated with Maytenus ilicifolia. The EGF expression in areas surrounding the ulcers in rats treated with $M$. ilicifolia was more pronounced than in the Tween $80(\mathrm{p}<0.05)$ treatment group (Figure 5A and $\mathrm{B}$ ). This healing activity evidenced by epidermal growth factor expression is associated with the antiulcerogenic process of chronic ulcer. So, the healing promoted by the Maytenus ilicifolia through increased EGF mRNA expression detected by RT-PCR, determined the action mechanism of the anti-ulcer activity.

\subsection{DPPH (2,2-Diphenyl -1 -picrylhydrazyl) and Hydroxyl Radical Scavenging Activity}

Oxygen-derived free radicals have recently been postulated to play an important role in the pathogenesis of acute gastric mucosal injury induced by ischemia-reperfusion, stress, ethanol and anti-inflammatory drugs in rats. Furthermore, it has been suggested that free radicals generated by neutrophils may be important factors in delaying the healing of acetic acid -induced chronic gastric ulcers in these animals [9].

It is well known that medicinal plants act as free radical scavengers, and as antilipoperoxidants and are helpful in protecting collagen from degradation caused by superoxide anion radicals [24]. Scavenging test have been extensively used to monitor biological activities of medicinal plants used in traditional medicines [25]. Traditionally, these studies are carried through spectrophotometry, with reactions involving free radicals and the most used substance for this purpose is the DPPH (1,1-diphenyl-2-picrylhydrazyl). Its "natural" color in ethanolic solution is dark violet, with a band of optic absorption centered at $520 \mathrm{~nm}$. This color changes to dark yellow, when it reacts with a substance that can donate a hydrogen atom [26]. However this transition of colors is usually difficult to detect because the optical bands of absorption are wide. So, in this work, Electron Spin Resonance Spectroscopy (ESR) was used, allowing the direct measurement of free radical concentration, with high sensitivity, to test the scavenging activity of Maytenus ilicifolia. Ito et al. [27] related that, among the free radicals involved the gastric ulcer pathogenesis, the oxygen composites with 4 electrons, the superoxide anion $\left(\mathrm{O}_{2}\right)$, the hydrogen peroxide $\left(\mathrm{H}_{2} \mathrm{O}_{2}\right)$ and the hydroxyl radical are the most important.

Figure 6A shows the ESR spectrum of DPPH after reaction with water $(0 \mathrm{mg} / \mathrm{ml})$ and different concentrations of $M$ ilicifolia. The intensity of the central line was used as the indicator of the free radical concentration. The fitting parameters from equation (1) of signal intensity (average of 3 spectrum) as function of extract concentrarion are: $\mathrm{A}=(4.6 \pm$ $0.3) \cdot 10^{-5}$ and $\mathrm{b}=(1.0 \pm 0.1) \mathrm{mg} / \mathrm{ml}$. Using this function, $\mathrm{a}$ value of $0.68 \pm 0.09 \mathrm{mg} / \mathrm{ml}$ was found to $\mathrm{IC}_{50}$.

Figure $6 \mathrm{~B}$ shows ESR spectra of spin-trapp DMPO-OH after reaction with Maytenus ilicifolia in different concentrations. The first central line was used as the indicator of free radical concentration. The fitting parameters from equation (1) of signal intensity (average of 3 spectrum) as function of extract concentrarion are: $\mathrm{A}=(2.2 \pm 0.2) \cdot 10^{-4}$ and $\mathrm{b}=(7 \pm 1) \mathrm{mg} / \mathrm{ml}$. Using this function, a value of $9 \pm 2 \mathrm{mg} / \mathrm{ml}$ was found to $\mathrm{IC}_{50}$. 
The anti-oxidative activity of the initial three crude extracts Hex (25 mg), EtOAc (230 mg) and BuOH $30 \mathrm{mg}$ (Figure 1) were tested by ESR using the DPPH radical $(500 \mu \mathrm{M})$ and EtOAc was the most antioxidant. Part of the crude extract EtOAc $(215 \mathrm{mg})$ was fractionated on a Sephadex LH-20 column ( $1 \mathrm{~m} \mathrm{x} 3 \mathrm{~cm}$ i.d., Pharmacia) eluted with $\mathrm{MeOH}$. A total of 25 fractions of $5 \mathrm{ml}$ each were

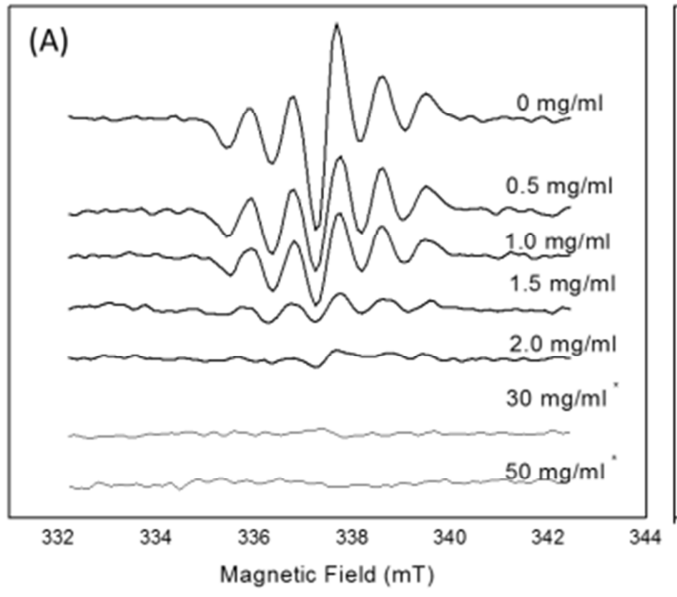

collected (figure 1). These fractions were also submitted to ESR experiments with DPPH to determine the most antioxidant fraction. (After TLC (Thin Layer Chromatography) analysis (Si gel 60 plates - Merck; mobile phase Hex/EtOAc 4:6; reagents vanillin and phosphomolybdic acid) fractions with similar Rfs (Retardation Factor) were combined.

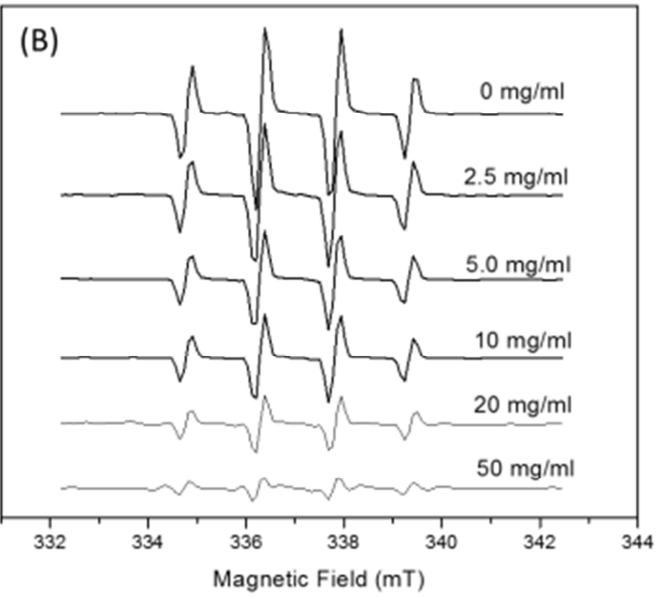

Figure 6. (A) ESR spectra of DPPH (1mM) after reaction with aqueous solutions of Maytenus Iliciofolia using lyophilized plant extract and dried leaves content of capsules diluted at same concentration used for in vivo experiments (30 and 50mg/ml). The DPPH signal intensity diminishes after reaction, demonstrating the antioxidative activity of plant. The fitting of experimental data of ESR signal intensity of DPPH radical as a function of extract concentration with equation (1) give a value of $0.68 \pm 0.09 \mathrm{mg} / \mathrm{ml}$ for $I_{50}$. (B): ESR spectra of DMPO-OH after reaction with aqueous solutions of Maytenus ilicifolia lyophilized extract in several concentrations demonstrating the free radical scavenging activity of plant. The fitting of experimental data of ESR signal intensity of DPPH radical as a function of extract concentration with equation (1) give a value of $9 \pm 2 \mathrm{mg} \mathrm{mg} / \mathrm{ml}$ for IC $\mathrm{Co}_{5}$.

The most active fraction F 14-15 was analyzed by ESI-MS via direct insertion. Figure 7 shows the mass spectrum of the most active fraction $\mathrm{F} 14-15$. This spectrum shows adduct ions of sodium $[\mathrm{M}+\mathrm{Na}]^{+}$and potassium $[\mathrm{M}+\mathrm{K}]^{+}$as well as ammonium adduct ions $\left[\mathrm{M}+\mathrm{NH}_{4}\right]^{+}$giving the same molecular mass at $\mathrm{m} / \mathrm{z} 459, \mathrm{~m} / \mathrm{z} 475, \mathrm{~m} / \mathrm{z} 489, \mathrm{~m} / \mathrm{z} 505$ and $\mathrm{m} / \mathrm{z}$ 534. Thus, with the molecular mass of the compounds obtained by ESI-MS, the search across natural product databases, particularly the Dictionary of Natural Products (Chapman \& Hall, version online) [28] was carried out. This information was cross with the genus Maytenus and was possible identify the compounds which belong to the pentacyclic triterpenes class. The presence of compounds of the triterpenoids class in the most active fraction of Maytenus ilicifolia reinforce the relationship between the anti-oxidative and anti-ulcerogenic properties of this class of compounds. [29] evaluated antiulcerogenic activity of friedelan-3 $\beta$-ol extracted from Maytenus ilicifolia (Celastraceae) and reported that these compounds did not decrease gastric ulcer. However, in our study, these triterpenes were not observed by mass spectrometry in the most active fraction.

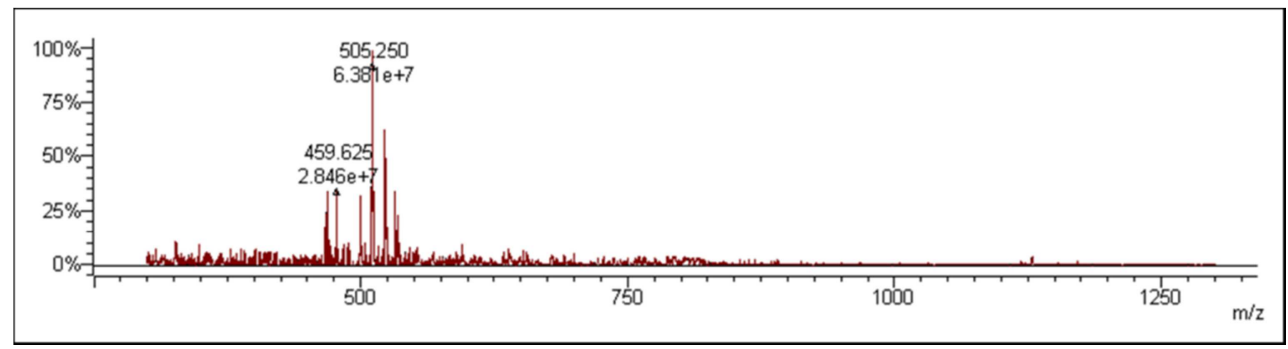

Figure 7. Mass spectrum of the active fraction $F$ 14-15 from M. ilicifolia.

\section{Conclusion}

In conclusion, the results of this work reinforce the antiulcer and gastroprotective effect of Maytenus ilicifolia and this pharmacological feature can be associated to its antioxidant properties and presence of triterpenes. The antiulcer action mechanism of $M$. ilicifolia involve epidermal growth factor expression detected by RT-PCR.

\section{Acknowledgements}

Thank to Wilson Orcini and Maira Couto for technical assistance, CNPq, CAPES and FAPESP for partial financial support. 


\section{References}

[1] Rattmann YD, Cipriani TR, Sassaki GL, Iacomini M, Rieck L, Marques MCA, et al. Nitric oxide-dependent vasorelaxation induced by extractive solutions and fractions of Maytenus ilicifolia Mart ex Reissek (Celastraceae) leaves. J Ethnopharmacol. 2006; 104 (3): 328-35.

[2] Ferreira PM, de Oliveira CN, de Oliveira AB, Lopes MJ, Alzamora F, Vieira MAR. A lyophilized aqueous extract of Maytenus ilicifolia leaves inhibits histamine-mediated acid secretion in isolated frog gastric mucosa. Planta. 2004; 219 (2): 319-24.

[3] Vellosa JCR, Khalil NM, Formenton VAF, Ximenes VF, Fonseca LM, Furlan M, et al. Antioxidant activity of Maytenus ilicifolia root bark. Fitoterapia. 2006; 77 (3): 243-4.

[4] Mota da Silva L, Boeing T, Somensi LB, Cury BJ, Bispo Steimbach VM, Oliveira Silveria AC de, et al. Evidence of gastric ulcer healing activity of Maytenus robusta Reissek: In vitro and in vivo studies. J Ethnopharmacol. 2015 4; 175: 7585.

[5] Cipriani TR, Mellinger CG, Souza LM De, Baggio CH, Freitas CS, Consuelo M, et al. Polygalacturonic acid: Another anti-ulcer polysaccharide from the medicinal plant Maytenus ilicifolia. Carbohydr Polym. 2009; 78 (2): 361-3.

[6] Jorge RM, Leite JP V, Oliveira AB, Tagliati CA. Evaluation of antinociceptive, anti-inflammatory and antiulcerogenic activities of Maytenus ilicifolia. 2004; 94: 93-100.

[7] De Paula ACB, Gracioso JS, Toma W, Hiruma-Lima CA, Carneiro EM, Brito ARMS. The antiulcer effect of Croton cajucara Benth in normoproteic and malnourished rats. Phytomedicine. 2008; 15 (10): 815-25.

[8] Wasicky A, Hernandes LS, Vetore-Neto A, Moreno PRH, Bacchi EM, Kato ETM, et al. Evaluation of gastroprotective activity of Passiflora alata. Rev Bras Farmacogn. 201525 (4): 407-12.

[9] Hamaishi K, Kojima R, Ito M. Anti-ulcer effect of tea catechin in rats. Biol Pharm Bull. 2006; 29 (11): 2206-13.

[10] Olfert ED, Cross BM, McWilliam A. Guide to the care and use of experimental animals. Can Counc Anim Care. 1993;

[11] Zimmermann M. Ethical guidelines for investigations of experimental pain in conscious animals. Pain. 1983; 16 (2): 109-10.

[12] Szelenyi I, Thiemer K. Distention ulcer as a model for testing of drugs for ulcerogenic side effects. Arch Toxicol. 1978; 41 (1): 99-105.

[13] Takagi K, Okabe S, Saziki R. A new method for the production of chronic gastric ulcer in rats and the effect of several drugs on its healing. Jpn J Pharmacol. 1969; 19 (3): 418-26.

[14] Konturek SJ, Brzozowski T, Majka J, Drozdowicz D, Stachura J. Adaptation of the gastric mucosa to stress. Scand J Gastroenterol. 1992; 27 (sup 193): 39-45.

[15] Chomczynski P, Sacchi N. Single-step method of RNA isolation by acid guanidinium thiocyanate-phenol-chloroform extraction. Anal Biochem. 1987; 162 (1): 156-9.

[16] Yokozawa T, Chen CP, Dong E, Tanaka T, Nonaka G-I, Nishioka I. Study on the inhibitory effect of tannins and flavonoids against the 1, 1-diphenyl-2-picrylhydrazyl radical. Biochem Pharmacol. 1998; 56 (2): 213-22.

[17] Pacheco A, Hespanha S, Oliveira RS. Brazilian Oral Research. 2014; 28.

[18] Miyahara MRM, Imamura PM, Freitas JC De, Leonor SJ, Baffa O, Kinoshita A, et al. Anti-oxidative and antiulcerogenic activity of Ipomoea imperati. Rev Bras Farmacogn. 2011; 21: 978-85.

[19] Barros Silva R, Santos NAG, Martins NM, Ferreira DAS, Barbosa Jr F, Oliveira Souza VC, et al. Caffeic acid phenethyl ester protects against the dopaminergic neuronal loss induced by 6-hydroxydopamine in rats. Neuroscience. 2013; 233 (0): 86-94.

[20] Oates PJ, Hakkinen JP. Studies on the mechanism of ethanolinduced gastric damage in rats. Gastroenterology. 1988; 94 (1): $10-21$.

[21] Cutz E, Chan W, Track NS, Goth A, Said SI. Release of vasoactive intestinal polypeptide in mast cells by histamine liberators. 1978.

[22] Milani S, Calabro A. Role of growth factors and their receptors in gastric ulcer healing. Microsc Res Tech. 2001; 53 (5): $360-71$.

[23] Konturek PC, Brzozowski T, Duda A, Kwiecien S, Löber S, Dembinski A, et al. Epidermal growth factor and prostaglandin E 2 accelerate mucosal recovery from stressinduced gastric lesions via inhibition of apoptosis. J Physiol. 2001; 95 (1): 361-7.

[24] Chen JH, Ho C-T. Antioxidant activities of caffeic acid and its related hydroxycinnamic acid compounds. J Agric Food Chem. 1997; 45 (7): 2374-8.

[25] Trouillas P, Calliste C-A, Allais D-P, Simon A, Marfak A, Delage $\mathrm{C}$, et al. Antioxidant, anti-inflammatory and antiproliferative properties of sixteen water plant extracts used in the Limousin countryside as herbal teas. Food Chem. 2003; 80 (3): 399-407.

[26] Molyneux P. The use of the stable free radical diphenylpicrylhydrazyl (DPPH) for estimating antioxidant activity. Songklanakarin J Sci Technol. 2004; 26 (2): 211-9.

[27] Ito M, Suzuki Y, Ishihara M, Suzuki Y. Anti-ulcer effects of antioxidants: effect of probucol. Eur J Pharmacol. 1998; 354 (2): 189-96.

[28] Chappman, Hall. Dictionary of Natural Products. CRC press.

[29] Queiroga CL, Silva GF, Dias PC, Possenti A, de Carvalho JE. Evaluation of the antiulcerogenic activity of friedelan-3 $\beta$-ol and friedelin isolated from Maytenus ilicifolia (Celastraceae). J Ethnopharmacol. 2000; 72 (3): 465-8. 